\title{
Foliar Application of Micronutrient Formulation on Growth, Yield and Cost Economics in Potato
}

\author{
H. Amarananjundeswara", Vishnuvardhan, P. S. Prasad, \\ S. Anilkumar, G. C. Sandhya and Soumya Shetty
}

All India Co-ordinated Research Project on Potato, Horticulture Research and Extension

Center, Hassan, Karnataka, India

*Corresponding author

\section{A B S T R A C T}

Keywords

Kufri Jyoti, Kharif, Micronutrients, Yield, $\mathrm{B}: \mathrm{C}$ ratio

Article Info

Accepted: 27 November 2020 Available Online: 10 December 2020
A field experiment was conducted under All India Co-ordinated Research Project on Potato at Horticulture Research and Extension Centre (HREC), Hassan, Karnataka consecutively for three years during Kharif season of 2015, 2016 and 2017 to study the effect of foliar application of micro-nutrient formulation on growth, yield and benefit cost ratio in potato $\mathrm{Cv}$ Kufri Jyoti. An experiment was laid out in Randomized Complete Block Design with four replications by adopting standard spacing of $60 \mathrm{~cm}$ x $20 \mathrm{~cm}$. In each formulation different concentration of micro-nutrients were used. The micro-nutrients and their formulation were sprayed at 30, 45 and 60 days after planting of tubers. Among the different formulations, foliar spray of UHSB-3 potato specific micro-nutrient formulation along with recommended dose of fertilizers recorded significantly highest A grade $(>75 \mathrm{~g})$ tubers $(11.78 \mathrm{t} / \mathrm{ha}), \mathrm{B}$ grade $(51-75 \mathrm{~g})$ tubers $(4.54 \mathrm{t} / \mathrm{ha}), \mathrm{C}$ grade $(26-50 \mathrm{~g})$ tubers $(3.06$ $\mathrm{t} / \mathrm{ha})$, total tuber yield $(21.07 \mathrm{t} / \mathrm{ha})$ and $\mathrm{B}: \mathrm{C}$ ratio of 2.22 . Therefore it was indicated that in all the three years, foliar spray of UHSB-3 potato specific micro-nutrient formulation along with recommended dose of fertilizers influenced progressively in terms of producing highest tuber yield and net returns.

\section{Introduction}

Potato is also called as poor man's strength or king of vegetables. It is a staple food prevailing all across the world with successful large scale production, consumption and availability. It is one of the most diverse and nutritious crops on the universe and can be grown almost all the continents (Khurana and Rana, 2008). Potato has the highest food value on a dry matter basis and it is also the most nutritious crop in proportion to its calorie value (Khurana, 1978). Potatoes produced in intensive management environments have high demand for plant nutrients. The higher potato yields can only be obtained through the soil application of optimal nutrient doses in balanced proportions (Poljak et al., 2007).

The nutrient management is made even more challenging due to nutrient leaching from 
relatively high irrigation rates required due to the combination of potato being grown commonly on sandy soils with low water holding capacity and extreme sensitivity to moisture stress (Barman et al., 2018). Most of the Indian soils are widely deficient in micronutrients especially $\mathrm{Zn}, \mathrm{Mn}, \mathrm{B}$ and Fe (Patel et al., 2015).

Micro-nutrients play a very important role in vital processes of plants. They increase the chlorophyll content of leaves, improve photosynthesis which intensify the assimilating activity of the whole plants (Marschner, 1995).

Spray of micro-element solution $(\mathrm{B}, \mathrm{Cu}, \mathrm{Mn}$, $\mathrm{Zn}$ and Mo) on potato leaves increased the uptake of N:P:K chlorophyll content, photosynthesis in leaves, promoted the tuber expansion and increased potato yield (Meng et al., 2004). Keeping in view of the above facts, an experiment was taken up to study the effect of foliar application of micro-nutrient formulation on growth and yield of potato.

\section{Materials and Methods}

The present investigation was conducted during Kharif season from 2015 to 2017 to study the effect of foliar application of micronutrient formulation on growth and yield of potato under AICRP-Potato at Horticultural Research and Extension Center, Hassan, Karnataka.

The soil of the experimental area was sandy loam having good physical, chemical properties and $\mathrm{pH}$ of the soil was 6.2.

The design followed was Randomized Complete Block Design with six treatments in four replications having a plot size of $3.6 \mathrm{~m} \mathrm{x}$ $3.0 \mathrm{~m}$ planted with the spacing of $60 \mathrm{~cm} \times 20$ $\mathrm{cm}$. The potato variety Kufri Jyoti was used as experimental seed material.

The treatments included under the study were as follows

\begin{tabular}{|c|c|}
\hline T1 & RDF of NPK (FYM 25 t/ha + N:P:K at 75:75:100 kg/ha) \\
\hline T2 & RDF + Foliar spray of Boron at $50 \mathrm{ppm}$ \\
\hline T3 & RDF + Foliar spray of Zinc at $150 \mathrm{ppm}$ \\
\hline T4 & RDF + Foliar spray of Boron at $50 \mathrm{ppm}+$ Zinc at $150 \mathrm{ppm}$ \\
\hline T5 & RDF + Foliar spray of vegetable special of IIHR $(5 \mathrm{~g} / \mathrm{l})$ \\
\hline T6 & RDF + Foliar spray of UHSB-3 potato specific nutrient formulation $(3 \mathrm{~g} / \mathrm{l})$ \\
\hline
\end{tabular}

The compositions of nutrient formulation planting of tubers. were sprayed at 30, 45 and 60 days after

\section{Composition of nutrient formulation}

\begin{tabular}{|c|c|c|}
\hline Sl. No. & Nutrient formulation & Composition \\
\hline $\mathbf{1}$ & IIHR Vegetable Special & $\begin{array}{c}\text { Zinc }(225 \mathrm{ppm}), \text { Boron }(50 \mathrm{ppm}), \text { Manganese } \\
(42.5 \mathrm{ppm}), \text { Iron }(105 \mathrm{ppm}), \text { Copper }(5 \mathrm{ppm})\end{array}$ \\
\hline $\mathbf{2}$ & $\begin{array}{c}\text { UHSB-3 potato specific } \\
\text { nutrient formulation }\end{array}$ & $\begin{array}{c}\text { Zinc }(200 \mathrm{ppm}) \text {, Manganese (75 ppm), Iron } \\
(100 \mathrm{ppm}), \text { Boron (75 ppm), Copper (25 } \\
\text { ppm) }\end{array}$ \\
\hline
\end{tabular}


An observations related to vegetative growth and yield attributes were recorded as follows.

\section{Growth parameters}

Plant emergence (\%) at 30 days after planting

Plant emergence $(\%)=\frac{\text { Total number of tubers germinated }}{\text { Total number of tubers planted }} \times 100$

\section{Plant height (cm)}

The maximum plant height was measured from the ground to the tip of longest leaf documented at 45 days after planting. The mean of five plants in each treatment was worked out.

\section{Number of shoots per plant}

The number of shoots per plant was recorded at 45 days after planting. The mean of the five plants in a treatment was worked out.

\section{Number of leaves per plant}

The number of fully grown, green and functional compound leaves were recorded from five randomly selected plants at 45 days after planting and average number of compound leaves per plant was calculated.

\section{Yield attributes}

\section{Grade wise tuber yield (t/ha)}

Out of total tubers obtained in each plot, all tubers were sorted in to four different grades based on their weight as extra large-A grade (>76g), large- B grade (51-75g), medium-C grade $(26-50 \mathrm{~g})$ and small-D grade $(<25 \mathrm{~g})$ and transformed into tonnes per hectare.

\section{Total tuber yield (t/ha)}

Total tuber yield $(\mathrm{t} / \mathrm{ha})=\mathrm{A}$-grade $+\mathrm{B}$-grade + C-grade + D-grade

\section{Cost economics (Rs/ha)}

The cost economics and benefit cost ratio were worked out at the end of the crop based on the cost of cultivation and net income obtained after marketing of tubers.

\section{Results and Discussion}

An observations on percentage of plant emergence, plant height, number of shoots, number of leaves, grade wise tuber yield, total tuber yield and benefit cost ratio were documented for three consecutive years from 2015 to 2017.

\section{Growth parameters}

The pooled data analysis for growth parameters indicated that among all the treatments, highest plant emergence of 85.72 per cent was reported in T6: RDF + Foliar spray of UHSB-3 potato specific nutrient formulation $(3 \mathrm{~g} / \mathrm{l})$ followed by $\mathrm{T} 5$ : RDF + Foliar spray of vegetable special of IIHR $(5 \mathrm{~g} / \mathrm{l})(83.46 \%)$ (Table 1$)$. The recommended dose of fertilizers along with foliar spray of UHSB-3 potato specific nutrient formulation $(3 \mathrm{~g} / \mathrm{l})$ recorded maximum plant height of about $64.53 \mathrm{~cm}$ followed by T5: RDF + Foliar spray of vegetable special of IIHR (5g/l) $(62.01 \mathrm{~cm})$ (Table 1). The highest number of shoots (4.07) and number of leaves (70.94) were noticed in T6: RDF + Foliar spray of UHSB-3 potato specific nutrient formulation (3g/l) followed by T5: RDF + Foliar spray of vegetable special of IIHR $(5 \mathrm{~g} / \mathrm{l})$ (3.77 and 68.13, respectively) (Table 2). An application of micro-nutrients showed significant effect on growth parameters was reported by Jafri et $a l ., 2013$. The secondary and micro-nutrients can help in increasing the foliage coverage at initial growth stages and in the later stages, which helps in translocation of assimilates is also responsible for higher yield. 
Table.1 Effect of foliar spray of micro-nutrients on plant emergence $(\%)$ and plant height $(\mathrm{cm})$ in potato

\begin{tabular}{|c|c|c|c|c|c|c|c|c|}
\hline \multirow[t]{2}{*}{ Treatments } & \multicolumn{4}{|c|}{ Plant emergence $(\%)$} & \multicolumn{4}{|c|}{ Plant height (cm) } \\
\hline & 2015 & 2016 & 2017 & Pooled & 2015 & 2016 & 2017 & Pooled \\
\hline T1- RDF of NPK & 86.67 & 86.64 & 65.56 & 79.62 & 49.80 & 44.70 & 50.75 & 48.42 \\
\hline T2- T1+ FS of Boron at $50 \mathrm{ppm}$ & 87.11 & 85.44 & 74.17 & 82.24 & 51.85 & 51.20 & 65.38 & 56.14 \\
\hline T3- T1+ FS of Zinc at $150 \mathrm{ppm}$ & 88.00 & 84.75 & 76.39 & 83.05 & 53.46 & 53.60 & 65.50 & $\mathbf{5 7 . 5 2}$ \\
\hline $\begin{array}{l}\text { T4- T1+ FS of Boron at } 50 \text { ppm + Zinc at } 150 \\
\text { ppm }\end{array}$ & 89.78 & 82.83 & 70.56 & 81.06 & 58.28 & 55.30 & 66.25 & 59.94 \\
\hline T5- T1+ FS of vegetable special of IIHR ( $5 \mathrm{~g} / \mathrm{l})$ & 85.78 & 87.39 & 77.22 & 83.46 & 62.39 & 56.25 & 67.38 & 62.01 \\
\hline $\begin{array}{l}\text { T6- T1+ FS of UHS-B potato specific nutrient } \\
\text { formulation }(3 \mathrm{~g} / \mathrm{l})\end{array}$ & 90.66 & 86.21 & 80.28 & 85.72 & 65.83 & 58.00 & 69.75 & 64.53 \\
\hline S. Em \pm & 3.65 & NS & 2.99 & 1.34 & 1.91 & 1.98 & 3.44 & 1.51 \\
\hline $\operatorname{CD}(p=0.05)$ & 11.50 & - & 9.01 & 3.96 & 5.74 & 5.96 & 10.37 & 4.75 \\
\hline CV $(\%)$ & 7.18 & - & 8.07 & 3.18 & 6.69 & 7.43 & 10.73 & 4.49 \\
\hline
\end{tabular}

FS- Foliar spray

NS- Non Significant

Table.2 Effect of foliar spray of micro-nutrients on number of shoots and leaves per plant at 45 days after planting in potato

\begin{tabular}{|c|c|c|c|c|c|c|c|c|}
\hline \multirow[t]{2}{*}{ Treatments } & \multicolumn{4}{|c|}{ Number of shoots } & \multicolumn{4}{|c|}{ Number of leaves } \\
\hline & 2015 & 2016 & 2017 & Pooled & 2015 & 2016 & 2017 & Pooled \\
\hline T1- RDF of NPK & 2.00 & 2.90 & 1.50 & 2.13 & 51.32 & 50.38 & 49.65 & 50.45 \\
\hline T2- T1+ FS of Boron at $50 \mathrm{ppm}$ & 2.75 & 3.28 & 2.25 & 2.76 & 55.45 & 56.25 & 55.35 & 55.68 \\
\hline T3- T1+ FS of Zinc at $150 \mathrm{ppm}$ & 3.25 & 3.43 & 2.75 & 3.14 & 62.80 & 59.75 & 61.20 & 61.25 \\
\hline $\begin{array}{l}\text { T4- T1+ FS of Boron at } 50 \mathrm{ppm}+\text { Zinc at } 150 \\
\text { ppm }\end{array}$ & 3.75 & 3.68 & 3.00 & 3.48 & 65.80 & 61.25 & 62.35 & 63.13 \\
\hline T5- T1+ FS of vegetable special of IIHR ( $5 \mathrm{~g} / \mathrm{l})$ & 4.00 & 4.05 & 3.25 & 3.77 & 67.83 & 70.75 & 65.80 & 68.13 \\
\hline $\begin{array}{l}\text { T6- T1+ FS of UHS-B potato specific nutrient } \\
\text { formulation }(3 \mathrm{~g} / \mathrm{l})\end{array}$ & 4.30 & 4.28 & 3.63 & 4.07 & 70.28 & 75.38 & 67.15 & 70.94 \\
\hline S. Em \pm & 0.28 & 0.29 & 0.25 & 0.12 & 2.98 & 3.26 & 3.63 & 1.27 \\
\hline $\mathrm{CD}(\mathrm{p}=0.05)$ & 0.84 & 0.87 & 0.74 & 0.37 & 8.98 & 9.81 & 10.95 & 4.00 \\
\hline CV $(\%)$ & 16.77 & 16.01 & 18.09 & 6.28 & 9.57 & 10.45 & 12.06 & 3.57 \\
\hline
\end{tabular}

FS- Foliar spray 
Table.3 Effect of foliar spray of micro-nutrients on grade wise tuber yield (t/ha) of potato

\begin{tabular}{|c|c|c|c|c|c|c|c|c|c|c|c|c|c|c|c|c|}
\hline \multirow[t]{2}{*}{ Treatment details } & \multicolumn{4}{|c|}{$\begin{array}{c}>76 \mathrm{~g} \text { tubers } \\
\text { (A-grade) (t/ha) }\end{array}$} & \multicolumn{4}{|c|}{$\begin{array}{l}\text { 51-75 g tubers } \\
\text { (B-grade) (t/ha) }\end{array}$} & \multicolumn{4}{|c|}{$\begin{array}{l}26-50 \mathrm{~g} \text { tubers } \\
(\mathrm{C} \text {-grade) (t/ha) }\end{array}$} & \multicolumn{4}{|c|}{$\begin{array}{c}25 \text { g tubers } \\
\text { (D-grade) (t/ha) }\end{array}$} \\
\hline & 2015 & 2016 & 2017 & Pooled & 2015 & 2016 & 2017 & Pooled & 2015 & 2016 & 2017 & Pooled & 2015 & 2016 & 2017 & $\begin{array}{c}\text { Pool } \\
\text { ed }\end{array}$ \\
\hline T1- RDF of NPK & 6.40 & 12.89 & 6.02 & 8.44 & 5.56 & 2.68 & 2.08 & 3.44 & 4.11 & 1.20 & 1.81 & 2.25 & 1.00 & 0.92 & 0.62 & 0.85 \\
\hline $\begin{array}{l}\text { T2- T1+ FS of Boron } \\
\text { at } 50 \mathrm{ppm}\end{array}$ & 7.11 & 14.89 & 6.10 & 9.37 & 4.76 & 2.82 & 2.79 & 3.46 & 2.57 & 1.41 & 1.92 & 2.08 & 2.28 & 0.99 & 0.81 & 1.36 \\
\hline $\begin{array}{l}\text { T3- T1+ FS of Zinc at } \\
150 \mathrm{ppm}\end{array}$ & 6.30 & 15.80 & 6.66 & 9.59 & 4.83 & 3.15 & 3.41 & 3.80 & 3.98 & 1.60 & 2.00 & 2.54 & 2.93 & 1.01 & 1.11 & 1.68 \\
\hline $\begin{array}{l}\text { T4- T1+ FS of Boron } \\
\text { at } 50 \mathrm{ppm}+\text { Zinc } \\
\text { at } 150 \mathrm{ppm}\end{array}$ & 5.93 & 16.22 & 7.41 & 9.85 & 4.56 & 3.33 & 3.62 & 3.84 & 5.09 & 1.72 & 2.11 & 2.92 & 1.94 & 1.11 & 1.27 & 1.44 \\
\hline $\begin{array}{l}\text { T5- T1+ FS of } \\
\text { vegetable special } \\
\text { of IIHR }(5 \mathrm{~g} / \mathrm{l})\end{array}$ & 6.71 & 17.47 & 8.70 & 10.96 & 4.75 & 3.66 & 3.88 & 4.10 & 4.42 & 1.80 & 2.19 & 2.86 & 2.62 & 1.16 & 1.42 & 1.73 \\
\hline $\begin{array}{l}\text { T6- T1+ FS of UHS-B } \\
\text { potato specific } \\
\text { nutrient } \\
\text { formulation }(3 \mathrm{~g} / \mathrm{l})\end{array}$ & 6.40 & 19.63 & 9.30 & 11.78 & 5.56 & 3.87 & 4.19 & 4.54 & 4.11 & 2.06 & 3.35 & 3.06 & 1.00 & 1.37 & 2.01 & 1.46 \\
\hline S Em+ & 0.45 & 0.48 & 0.36 & 0.50 & 0.22 & 0.10 & 0.19 & 0.20 & 0.25 & 0.07 & 0.12 & 0.23 & 0.07 & 0.06 & 0.13 & NS \\
\hline$C D(p=0.05)$ & 1.43 & 1.44 & 1.07 & 1.51 & 0.50 & 0.31 & 0.58 & 0.61 & 0.78 & 0.22 & 0.37 & 0.69 & 0.23 & 0.18 & 0.38 & - \\
\hline $\operatorname{CV}(\%)$ & 13.93 & 5.91 & 9.66 & 10.02 & 6.30 & 6.24 & 11.51 & 10.45 & 11.70 & 8.89 & 11.08 & 17.55 & 6.32 & 10.65 & 19.78 & - \\
\hline
\end{tabular}

FS- Foliar spray

NS- Non Significant 
Table.4 Effect of foliar spray of micro-nutrients on total tuber yield ( $\mathrm{t} / \mathrm{ha}$ ) of potato and benefit cost ratio

\begin{tabular}{|c|c|c|c|c|c|c|c|c|}
\hline \multirow[t]{2}{*}{ Treatment details } & \multicolumn{4}{|c|}{ Total tuber yield (t/ha) at 90 DAP } & \multicolumn{4}{|c|}{$\mathrm{B}: \mathrm{C}$ ratio } \\
\hline & 2015 & 2016 & 2017 & Pooled & 2015 & 2016 & 2017 & Pooled \\
\hline T1- RDF of NPK & 17.64 & 17.69 & 10.53 & 15.29 & 1.91 & 1.91 & 1.14 & 1.65 \\
\hline T2- T1+ FS of Boron at $50 \mathrm{ppm}$ & 17.33 & 20.11 & 11.62 & 16.35 & 1.86 & 2.16 & 1.25 & 1.76 \\
\hline T3- T1+ FS of Zinc at 150 ppm & 18.47 & 21.56 & 13.19 & 17.74 & 1.93 & 2.26 & 1.38 & 1.86 \\
\hline T4- T1+ FS of Boron at $50 \mathrm{ppm}+$ Zinc at $150 \mathrm{ppm}$ & 17.74 & 22.38 & 14.42 & 18.18 & 1.85 & 2.33 & 1.50 & 1.89 \\
\hline T5- T1+ FS of vegetable special of IIHR (5 g/l) & 18.99 & 24.09 & 16.19 & 19.76 & 2.00 & 2.54 & 1.71 & 2.08 \\
\hline $\begin{array}{l}\text { T6- T1+ FS of UHS-B potato specific nutrient } \\
\text { formulation }(3 \mathrm{~g} / \mathrm{l})\end{array}$ & 17.44 & 26.92 & 18.85 & 21.07 & 1.84 & 2.84 & 1.99 & 2.22 \\
\hline S Em+ & 0.75 & 0.08 & 0.44 & 0.73 & - & - & - & - \\
\hline $\mathrm{CD}(\mathrm{p}=\mathbf{0 . 0 5})$ & 2.36 & 0.24 & 1.33 & 2.20 & - & - & - & - \\
\hline $\mathrm{CV}(\%)$ & 8.03 & 6.36 & 6.23 & 8.07 & - & - & - & - \\
\hline
\end{tabular}

DAP: Days After Planting

FS- Foliar spray

Table.5 Effect of foliar spray of micro-nutrients on potato and their cost economics per hectare (Kharif-2015)

\begin{tabular}{|c|c|c|c|c|c|c|c|c|c|}
\hline \multirow[t]{2}{*}{ Treatments } & \multirow[t]{2}{*}{$\begin{array}{l}\text { Yield } \\
\text { (t/ha) }\end{array}$} & \multicolumn{5}{|c|}{$\begin{array}{l}\text { Cost of Cultivation } \\
\text { (Rs./ha) }\end{array}$} & \multicolumn{2}{|c|}{ Income (Rs./ha) } & \multirow[t]{2}{*}{$\begin{array}{c}\text { B:C } \\
\text { Ratio }\end{array}$} \\
\hline & & $\begin{array}{c}\text { Seed Tuber } \\
\text { Cost }\end{array}$ & $\begin{array}{l}\text { Fertilizers + } \\
\text { Pesticides } \\
\text { Cost }\end{array}$ & $\begin{array}{c}\text { Micro } \\
\text { Nutrient Cost }\end{array}$ & $\begin{array}{c}\text { Cultivation } \\
\text { Cost }\end{array}$ & $\begin{array}{c}\text { Total } \\
\text { Expenditure }\end{array}$ & Gross Income & $\begin{array}{c}\text { Net } \\
\text { Income }\end{array}$ & \\
\hline T1- RDF of NPK & 17.64 & 22,500 & 17,100 & 0.00 & 52,900 & 92,500 & $1,76,400$ & 83,900 & 1.91 \\
\hline T2- T1+ FS of Boron at $50 \mathrm{ppm}$ & 17.33 & 22,500 & 17,100 & 500 & 52,900 & 93,000 & $1,73,300$ & 80,300 & 1.86 \\
\hline T3- T1+ FS of Zinc at $150 \mathrm{ppm}$ & 18.47 & 22,500 & 17,100 & 2,900 & 52,900 & 95,400 & $1,84,700$ & 89,300 & 1.93 \\
\hline $\begin{array}{l}\text { T4- T1+ FS of Boron at } 50 \mathrm{ppm} \\
\text { + Zinc at } 150 \mathrm{ppm}\end{array}$ & 17.74 & 22,500 & 17,100 & 3,400 & 52,900 & 95,900 & $1,77,400$ & 81,500 & 1.85 \\
\hline $\begin{array}{l}\text { T5- T1+ FS of vegetable special of } \\
\text { IIHR (5 g/l) }\end{array}$ & 18.99 & 22,500 & 17,100 & 2,250 & 52,900 & 94,750 & $1,89,900$ & 95,150 & 2.00 \\
\hline $\begin{array}{l}\text { T6- T1+ FS of UHS-B potato } \\
\text { specific nutrient formulation } \\
(3 \mathrm{~g} / \mathrm{l})\end{array}$ & 17.44 & 22,500 & 17,100 & 2,250 & 52,900 & 94,750 & $1,74,400$ & 79,650 & 1.84 \\
\hline
\end{tabular}

FS-Foliar Spray

Note: Seed Rate - 1500 kg/ha

Seed Tuber Cost - Rs. 15/kg

Market Sale Price -Rs. 10/kg 
Table.6 Effect of foliar spray of micro-nutrients on potato and their cost economics per hectare (Kharif-2016)

\begin{tabular}{|c|c|c|c|c|c|c|c|c|c|}
\hline \multirow[t]{2}{*}{ Treatments } & \multirow[t]{2}{*}{$\begin{array}{l}\text { Yield } \\
(\mathrm{t} / \mathrm{ha})\end{array}$} & \multicolumn{5}{|c|}{$\begin{array}{l}\text { Cost of Cultivation } \\
\text { (Rs./ha) }\end{array}$} & \multicolumn{2}{|c|}{ Income (Rs./ha) } & \multirow[t]{2}{*}{$\begin{array}{c}\text { B:C } \\
\text { Ratio }\end{array}$} \\
\hline & & $\begin{array}{c}\text { Seed Tuber } \\
\text { Cost }\end{array}$ & $\begin{array}{c}\text { Fertilizers + } \\
\text { Pesticides } \\
\text { Cost }\end{array}$ & $\begin{array}{c}\text { Micro } \\
\text { Nutrient Cost }\end{array}$ & $\begin{array}{c}\text { Cultivation } \\
\text { Cost }\end{array}$ & $\begin{array}{c}\text { Total } \\
\text { Expenditure }\end{array}$ & Gross Income & $\begin{array}{l}\text { Net } \\
\text { Income }\end{array}$ & \\
\hline T1- RDF of NPK & 17.69 & 22,500 & 17,100 & 0.00 & 52,900 & 92,500 & $1,76,900$ & 84,400 & 1.91 \\
\hline T2- T1+ FS of Boron at $50 \mathrm{ppm}$ & 20.11 & 22,500 & 17,100 & 500 & 52,900 & 93,000 & $2,01,100$ & $1,08,100$ & 2.16 \\
\hline T3- T1+ FS of Zinc at $150 \mathrm{ppm}$ & 21.56 & 22,500 & 17,100 & 2,900 & 52,900 & 95,400 & $2,15,600$ & $1,20,200$ & 2.26 \\
\hline $\begin{array}{l}\text { T4- T1+ FS of Boron at } 50 \mathrm{ppm} \\
\text { + Zinc at } 150 \mathrm{ppm}\end{array}$ & 22.38 & 22,500 & 17,100 & 3,400 & 52,900 & 95,900 & $2,23,800$ & $1,27,900$ & 2.33 \\
\hline $\begin{array}{l}\text { T5- T1+ FS of vegetable special of IIHR (5 } \\
\text { g/l) }\end{array}$ & 24.09 & 22,500 & 17,100 & 2,250 & 52,900 & 94,750 & $2,40,900$ & $1,46,150$ & 2.54 \\
\hline $\begin{array}{l}\text { T6- T1+ FS of UHS-B potato } \\
\text { specific nutrient formulation }(3 \mathrm{~g} / \mathrm{l})\end{array}$ & 26.92 & 22,500 & 17,100 & 2,250 & 52,900 & 94,750 & $2,69,200$ & $1,74,450$ & 2.84 \\
\hline
\end{tabular}

FS- Foliar Spray

Note: Seed Rate - $1500 \mathrm{~kg} / \mathrm{ha}$

Seed Tuber Cost - Rs. 15/kg

Market Sale Price -Rs. 10/kg

Table.7 Effect of foliar spray of micro-nutrients on potato and their cost economics per hectare (Kharif-2017)

\begin{tabular}{|c|c|c|c|c|c|c|c|c|c|}
\hline \multirow[t]{2}{*}{ Treatments } & \multirow[t]{2}{*}{$\begin{array}{l}\text { Yield } \\
\text { (t/ha) }\end{array}$} & \multicolumn{5}{|c|}{$\begin{array}{l}\text { Cost of Cultivation } \\
\text { (Rs./ha) }\end{array}$} & \multicolumn{2}{|c|}{ Income (Rs./ha) } & \multirow[t]{2}{*}{$\begin{array}{c}\text { B:C } \\
\text { Ratio }\end{array}$} \\
\hline & & $\begin{array}{l}\text { Seed Tuber } \\
\text { Cost }\end{array}$ & $\begin{array}{c}\text { Fertilizers + } \\
\text { Pesticides Cost }\end{array}$ & $\begin{array}{c}\text { Micro } \\
\text { Nutrient Cost }\end{array}$ & $\begin{array}{l}\text { Cultivation } \\
\text { Cost }\end{array}$ & $\begin{array}{c}\text { Total } \\
\text { Expenditure }\end{array}$ & $\begin{array}{l}\text { Gross } \\
\text { Income }\end{array}$ & $\begin{array}{c}\text { Net } \\
\text { Income }\end{array}$ & \\
\hline T1- RDF of NPK & 10.53 & 22,500 & 17,100 & 0.00 & 52,900 & 92,500 & $1,05,300$ & 12,800 & 1.14 \\
\hline T2- T1+ FS of Boron at 50 ppm & 11.62 & 22,500 & 17,100 & 500 & 52,900 & 93,000 & $1,16,200$ & 23,200 & 1.25 \\
\hline T3- T1+ FS of Zinc at $150 \mathrm{ppm}$ & 13.19 & 22,500 & 17,100 & 2,900 & 52,900 & 95,400 & $1,31,900$ & 36,500 & 1.38 \\
\hline $\begin{array}{l}\text { T4- T1+ FS of Boron at } 50 \mathrm{ppm} \\
\text { + Zinc at } 150 \mathrm{ppm}\end{array}$ & 14.42 & 22,500 & 17,100 & 3,400 & 52,900 & 95,900 & $1,44,200$ & 48,300 & 1.50 \\
\hline $\begin{array}{l}\text { T5- T1+ FS of vegetable special of } \\
\text { IIHR }(5 \mathrm{~g} / \mathrm{l})\end{array}$ & 16.19 & 22,500 & 17,100 & 2,250 & 52,900 & 94,750 & $1,61,900$ & 67,150 & 1.71 \\
\hline $\begin{array}{l}\text { T6- T1+ FS of UHS-B potato } \\
\text { specific nutrient formulation }(3 \mathrm{~g} / \mathrm{l})\end{array}$ & 18.85 & 22,500 & 17,100 & 2,250 & 52,900 & 94,750 & $1,88,500$ & 93,750 & 1.99 \\
\hline
\end{tabular}

FS-Foliar Spray

Note: Seed Rate - 1500 kg/ha

Seed Tuber Cost - Rs. 15/kg

Market Sale Price -Rs. 10/kg 
Fig.1 Effect of foliar spray of micro-nutrients on total tuber yield ( $\mathrm{t} / \mathrm{ha})$ of potato and $\mathrm{B}$ : $\mathrm{C}$ ratio

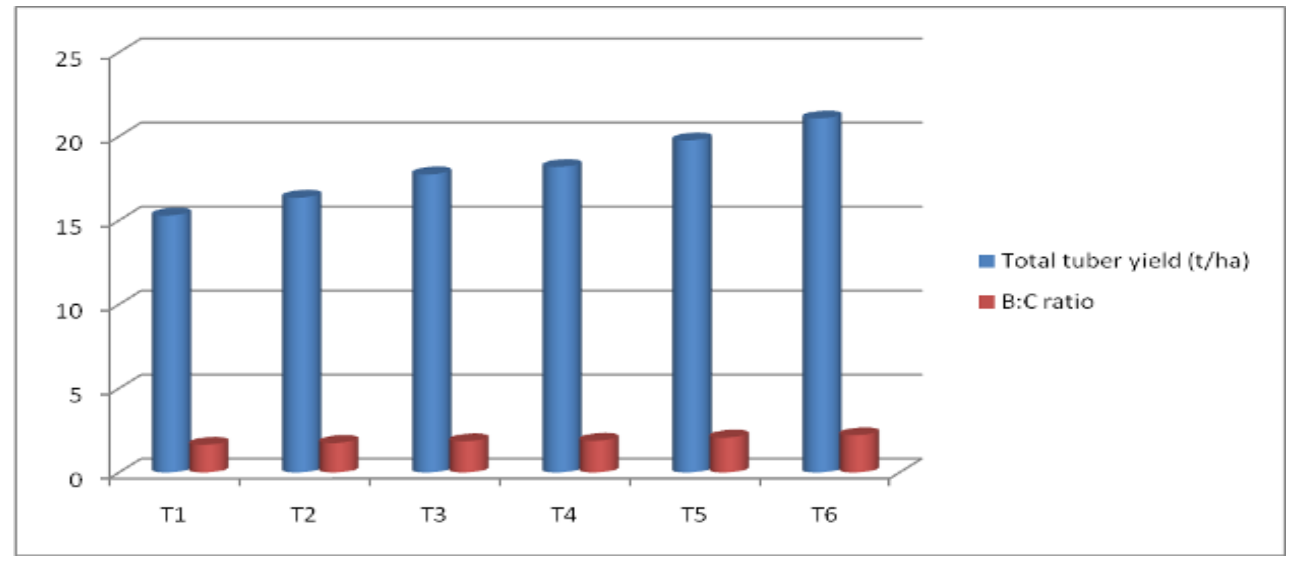

Plate.1 View of best micro-nutrient formulation treatments of T6 and T5

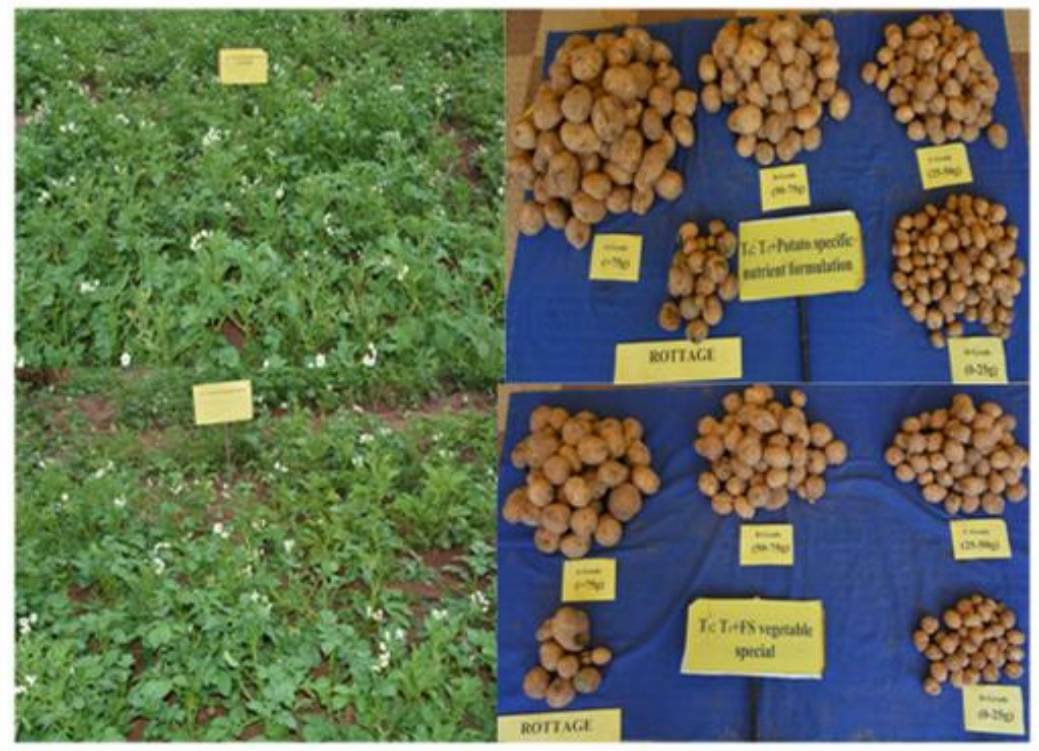

These results are in good accordance with those obtained by Bari et al., (2001), Parmar et al., (2016), Moinuddin et al., (2017) and Singh et al., (2018).

\section{Yield parameters}

The pooled data over three years revealed that, highest A grade (>75 g) tubers of 11.78 t/ha documented in foliar spray of UHSB-3 potato specific nutrient formulation along with soil application of RDF followed by T5: $\mathrm{RDF}+$ Foliar spray of vegetable special of
IIHR (5g/l) (10.96 t/ha) (Table 3). The highest $\mathrm{B}$ grade $(51-75 \mathrm{~g})$ and $\mathrm{C}$ grade $(26-50 \mathrm{~g})$ tubers of 4.54 and $3.06 \mathrm{t} / \mathrm{ha}$, respectively registered in T6: RDF + Foliar spray of UHSB-3 potato specific nutrient formulation (3g/l) followed by T5: RDF + Foliar spray of vegetable special of IIHR $(5 \mathrm{~g} / \mathrm{l})$ wherein recorded 4.10 and $2.86 \mathrm{t} / \mathrm{ha}$, respectively (Table 3). However, highest total tuber yield was documented in T6: RDF + Foliar spray of UHSB-3 potato specific nutrient formulation (3g/l) (21.07 t/ha) followed by T5: RDF + Foliar spray of vegetable special of IIHR 
(5g/l) with 19.76 t/ha (Table 4, Fig.1 \& Plate 1). The foliar fertilization has potential to play an important role in potato production. The secondary and micro-nutrients helps in increasing the foliage coverage at initial growth stages and in the later stages, which helps in translocation of assimilates is also responsible for higher yield. An increase in tuber yield was due to micro-nutrient application, which may be attributed to the enhanced photosynthesis activity resulting into the increased production and accumulation of carbohydrates and favorable effect on vegetative growth (Basavarajeswari et al., 2008 and Parmar et al., 2016) in different vegetable crops. An application of micro-nutrients significantly increased the yield of large and medium size grade tubers and decreased proportionately small tubers (Vinod Kumar et al., 2008 and Bari et al., 2001).

The pooled data of cost benefit ratio obtained from foliar application of different micronutrient formulation varied from 2.22 to 1.65 in accordance with the prevailing market prices. The treatment with (T6) RDF + Foliar spray of USB-3 potato specific nutrient formulation $(3 \mathrm{~g} / \mathrm{l})$, which significantly out yielded over control, gave comparatively higher yield than other treatments and also documented highest cost benefit ratio of 2.22 followed by T5: RDF + Foliar spray of vegetable special of IIHR $(5 \mathrm{~g} / \mathrm{l})$ (2.08) (Table $4 \&$ Fig. 1). In all the three consecutive years cost economics was calculated for all the treatments, but T6: RDF + Foliar spray of UHSB-3 potato specific nutrient formulation (3g/l) gave higher net returns followed by T5: RDF + Foliar spray of vegetable special of IIHR (5g/l) (Table 5, 6 \& 7).

In the present investigation, it is concluded that foliar application of UHSB-3 potato specific nutrient formulation $(3 \mathrm{~g} / \mathrm{l})$ along with soil application of RDF (75:75:100 kg/ha of $\mathrm{N}: \mathrm{P}: \mathrm{K})$ and FYM (25 t/ha) is found most effective in recording maximum growth and tuber yields. Therefore, foliar spray of UHS-3 potato specific nutrient formulation $(3 \mathrm{~g} / \mathrm{l})$ along with RDF may be recommended to the potato growers to get higher growth and tuber yields and to increase the overall production of potato in Southern Dry Zone of Karnataka.

\section{References}

Bari, M. S., Rabbani, M. G., Rahman, M. S., Islam, M. J. and Hoque, M.R. 2001. Effect of zinc, boron, sulphar and magnesium on growth and yield of potato. Pak J. Biol. Sci. 4(9):10901093.

Barman, K.S., Kumar, A, Kasera, S. and Ram, B. 2018. Integrated nutrient management in potato (Solanum tuberosum) cv. Kufri Ashoka. J. of Pharma Phytochem. SP1:1936-1938.

Basavarajeshwari, C. P., Hosamani, R. M., Ajjappalavara, P. S. and Naik, B. H. 2008. Effect of foliar application of micro-nutrients on growth and yield components of tomato (Lycopersicon esculentum Mill.). Karnataka J. Agricl Sci. 21(3):428-430.

Jafri, S., Shiranirad, A. H., Daneshian, J. and Rokhazadi, A. 2013. Effects of nitrogen application and spraying of boron and manganese on growth traits of two potato cultivars. Int. J. Biosci. 3(9). 298-303.

Khurana, S. M. P. 1978. Higher to less values of International Son Potato Souvenir Central Potato Station, Jalandhar, India.

Khurana, S.C. and Rana, M.K. 2008. Potato: Olericulture in India, $1^{\text {st }}$ edn, Kalyani Publishers, New Delhi.

Marschner, H. 1995. Mineral nutrition of higher plants. $2^{\text {nd }}$ Edn. Academic Press, London, 889.

Meng, M. L., Yic, M. F., Jun, Y., Lin, Y.Z. 
2004. Research progress on cultivation and physiology of potato in China $5^{\text {th }}$ world Potato Congress, 16.

Moinuddin, G., Jash, S., Sarkar, A. and Dasgupta, S. 2017. Response of potato (Solanum tuberosum L.) to foliar application of macro and micronutrients in the red and lateritic zone of west bengal. J. Crop and Weed. 13(1): 185-188.

Parmar, M., Nandre, B. M., and Pawar Y. 2016. Influence of foliar supplementation of zinc and manganese on yield and quality of potato, Solanum tuberosum L. Int. J. Farm Sci. 6(1): 69-73.

Patel, K. S., Chikhlekar, S., Ramteke, S., Sahu, B. L., Dahariya, N. S. and Sharma, R. 2015. Micro-nutrient status in soil of Central India, Americal J. Pl. Sci. 6:3025-3037.

Poljak, M, Herak-custuc, M, Horvat, T., Coga, L. and Magic, A. 2007. Effects of nitrogen nutrition on potato tuber composition and yield. Cereal Research Communications, 35:937940.

Singh, S. K., Sharma, M., Reddy, K.R. and Venkatesh, T. 2018. Integrated application of boron and sulphur to improve quality and economic yield in potato. J. Environ Bio. 39: 204-210.

Vinod kumar, Vyakarnahal, B. S., Basavaraj, N., Srikant, K. and Gouda, S. M. 2008. Influence of micro-nutrients on growth and yield of potato (Solanum tuberosum) cultivars. Indian J. Agril Sci. 78(9): 752-6.

\section{How to cite this article:}

Amarananjundeswara, H., Vishnuvardhan, P. S. Prasad, S. Anilkumar, G. C. Sandhya and Soumya Shetty. 2020. Foliar Application of Micronutrient Formulation on Growth, Yield and Cost Economics in Potato. Int.J.Curr.Microbiol.App.Sci. 9(12): 3151-3160. doi: https://doi.org/10.20546/ijcmas.2020.912.375 